\title{
Comprehension of Two Modalities: Endovascular Coiling and Microsurgical Clipping in Treatment of Intracranial Aneurysms
}

\author{
See Sung Choi, MD', Se Jeong Jeon, MD'1
}

\begin{abstract}
A subarachnoid hemorrhage (SAH) is caused by rupture of an intracranial aneurysm. SAHs have significant morbidity and mortality worldwide. Since the 1970s, clipping of intracranial aneurysms has been the standard treatment for SAHs. In the 1990s, a detachable platinum coil device was introduced. This device led to the development of endovascular techniques and reduced the risk of further rupture without a craniotomy. Thus, endovascular coiling has become widely used in patients with ruptured and unruptured intracranial aneurysms (UIAs). Regardless of the treatment technique (clipping or endovascular coiling), the goal of occluding aneurysms is the prevention of rebleeding in ruptured aneurysms and rupture in UIAs. These two treatment techniques have advantages and disadvantages. The question of which technique is more effective in patients with intracranial aneurysms remains controversial. The objective of this article is to provide a comprehensive review of the effect of coiling versus clipping of intracranial aneurysms.
\end{abstract}

Key Words : Aneurysm; Clipping; Coiling; Subarachnoid hemorrhage

An aneurysm is a dilatation of a vascular lumen due to weakness of all vessel wall layers. Most cerebral aneurysms probably result from hemodynamicallyinduced degenerative vascular injuries by abnormal hemodynamic shear stresses on the walls of large cerebral arteries, particularly at bifurcation points. It has been reported that $90 \%$ of all intracranial aneurysms arise from the anterior circulation $(1,2)$. Most aneurysms are asymptomatic until they rupture; when aneurysms rupture, they are associated with significant morbidity and mortality. About $15 \%$ of patients die before reaching the hospital. The 30-day

'Department of Radiology, Wonkwang University Hospital, Korea Received November 7, 2009;

accepted after revision December 24, 2009.

Correspondence to: See Sung Choi, MD, Department of Radiology, Wonkwang University Hospital, 344-2, Shinyong-dong, Iksan, Jeonbuk 570-711, Korea.

Tel. 82-63-859-1920 Fax. 82-63-851-4749

E-mail: sschoi@wonkwang.ac.kr

Neurointervention 2010;5:1-7 mortality rate is $45 \%$. Approximately one-half of the survivors sustain irreversible brain damage. Although few cases have been reported to resolve spontaneously in unruptured intracranial aneurysms (UIAs), direct treatment is usually recommended and should be treated in ruptured aneurysms $(3-6)$.

The true incidence of intracranial aneurysms is unknown, but is estimated at $0.4-6 \%$ of the population (7). The rate of SAH due to rupture of intracranial aneurysms is $6-8$ per 100,000 in Western countries and 7-11 per 100,000 in Korea (2, 3, 8-11). Ruptured aneurysms can be treated by microsurgical clipping or endovascular coiling because in so doing, the risks and benefits of further bleeding are prevented $(2,9,10)$. In 1990, the Guglielmi detachable coil (GDC; Boston Scientific/Target Therapeutics, Freemont, CA, USA) was introduced, and the coil was approved by the US Food and Drugs Administration (FDA) 5 years later (9). Since 1995, coiling has become widely used in ruptured aneurysms and UIAs, and many studies have reported comparisons between clipping and coiling. 
The International Subarachnoid Aneurysm Trial (ISAT) was a multicenter prospective randomized trial comparing clipping and coiling in 2002 and 2005. According to the results, the outcome in terms of survival free of disability at 1 year, was significantly better and maintained for up to 7 years with endovascular coiling $(10,12)$. The results of ISAT have affected the approach to patients with cerebral aneurysms, not only with respect to the treatment mode, but also resource allocation (2). However, the long-term efficacy of these two treatment modalities remains controversial. The purpose of this review based on published results was to understand the two treatment modalities (coiling and clipping) and to clarify which treatment modality will provide the best outcome with the lowest risk for each patient type.

\section{Management Philosophy}

Determining a treatment approach to ruptured aneurysms and UIAs is influenced by several factors, such as patient status and aneurysm characteristics (10, 12, 13). The indications for treatment of aneurysms were as follows: 1) all ruptured aneurysms; 2) for UIAs, symptomatic intradural UIAs of all size, coexisting or remaining aneurysms of all sizes in patients with SAH due to another treated aneurysm, young patients with UIAs $<10 \mathrm{~mm}$ in size, small aneurysms approaching the $10 \mathrm{~mm}$ size, UIAs with daughter sac formation and other unique hemodynamic features, patients with a positive family history of SAH or aneurysms, and asymptomatic aneurysms $\geq 10 \mathrm{~mm}$ in size (13). The main treatment methods are coiling and clipping; a recently combined approach can lead to better outcomes than a single modality $(14,15)$. Treatment outcome is assessed by morbidity, mortality, and functional outcome with the use of validated scales (13). Patient age is a strong predictor of surgical outcome, and the size and location of an aneurysm predict both surgical and endovascular outcomes (13, $16,17)$. The choice of modality depends upon the risks and benefits of each treatment.

\section{Microsurgical Treatment (Clipping)}

Until recently, clipping has been the definitive treatment modality because the rate of complete obliteration of aneurysms is $82-96.4 \%(8,10,12,18)$. Some aneurysms can be managed more safely by clipping, as follows: aneurysms $>20 \mathrm{~mm}$ and $<2 \mathrm{~mm}$ in size, blister aneurysms, fusiform aneurysms in a vessel that does not have collaterals, 2 or more critical branches in the aneurysmal neck, critical branches from the sac or fundus of the aneurysm, tortuous intracranial arteries, patients $<40$ years of age, and aneurysms located in the middle cerebral artery $(3,18-23)$. Alternatively, clipping is less effective when the patient is elderly, the aneurysm is located in the posterior circulation, and in patients with poor health status on admission $(24,25)$. Sometimes, aneurysmal remnant or vessel occlusion develops in large aneurysms, in patients with cerebrovascular atherosclerosis, or after multiple attempts to place clips. Also, there is a higher risk of secondary cerebral ischemia and surgical complications, such as intra-operative rupture, major vessel occlusion, cerebral contusion, or intracerebral hematomas $(26,27)$. The surgical morbidity and mortality have been reported to be $2.5-17 \%(27-29)$.

\section{Endovascular Treatment (Coiling)}

Since GDC was introduced, endovascular treatment of intracranial aneurysms has been rapidly undergoing major developments worldwide. This treatment method could avoid craniotomy and is associated with a decreased recovery time. There are some disadvantages to coiling, such as a high rate of incomplete obliteration and recurrence rate, a high risk of rebleeding, increased costs, and the need for angiographic follow-up $(3,29$ $31)$. In the early days of coiling, indications for endovascular treatment were restricted to the surgically "difficult" or inoperable lesions, lesions in the posterior circulation, refusal to undergo surgery, and old age. However, with abundant experience and the development of devices and techniques, the indications for coiling have widened $(9,18,20)$. Currently, this treatment has gained wide acceptance as a first treatment option, especially after a large study that compared clipping to coiling showed favorable results $(10,32)$. Many studies have been reported involving comparisons of efficacy and effectiveness between coiling and clipping. Most of these studies have demonstrated better outcome than surgery, but the long-term efficacy of coiling is not proven.

\section{Ruptured Aneurysms}

The prognosis of ruptured aneurysms is poor; about one-half of the patients die due to SAH or to secondary complications, and many survivors need rehabilitation or skilled nursing facility $(3,8,28,32)$. The policy of early aneurysm occlusion has led to progressively 


\section{Comprehension of Two Modalities}

lower rates of rebleeding $(8,10)$. Based on previous reports by advocates of endovascular coiling, coiling is considered to have the same or better efficacy than clipping; however, many biases exist in the reports. Both methods are suitable for treatment of ruptured intracranial aneurysms and there is consensus on this issue. Nevertheless, there is disagreement regarding which method is more favorable.

\section{Vasospasm and Infarction}

Vasospasm and infarction are the major causes of death and disability after SAH $(3,33)$. The incidence of vasospasm is $70 \%$, and $40 \%$ of these patients are symptomatic. Also, vasospasm is significantly more frequent in patients with ruptured aneurysms because it is related to the presence of adherent clots along cerebral arteries, and leads to vasospasm and infarction $(3,8,12,27)$. The risk of infarction is higher in patients with vasospasm and in those with clipping. Infarction and vasospasm more often develop in clipped patients than coiling, but the difference is not significant $(8,12$, $27,34)$. Vasospasm and infarction develop more frequently in patients with clipping despite early and clear removal of blood in the subarachnoid space by surgery, suggesting that surgical manipulation of the arteries causes local vasospasm that leads to ischemic deficits $(3,8,27)$. Vasospasm, treatment modality, and aneurysm rupture are predictors for cerebral infarction, but treatment modality and aneurysm rupture have been shown to have less of an impact $(3,8,12,27,34$, $35)$.

\section{Hydrocephalus}

Hydrocephalus is a well-known sequela of SAH (3, 18). Like vasospasm, the amount and severity of SAH is a predictor of hydrocephalus (36-38). Few studies have evaluated the effect of aneurysmal treatment modality on permanent shunting requirements. According to these studies, the incidence ranges from $6-67 \%$ and most of them have reported that coiling is more associated with increased risk than clipping (range of shunt requirement [clipped vs. coiled], 4.4$23 \%$ vs. $6-47.1 \%$, respectively; $3,18,32$ ). The reason why the rate of hydrocephalus is higher in coiling is that blood or clots are removed by irrigation or evacuation during surgery, but not during intravascular coiling (32).

\section{Incomplete Occlusion and Rebleeding}

Many studies have reported that the incomplete occlusion rate of coiling is higher than clipping (rate of incomplete occlusion [clipped vs. coiled], 0.0-26.3\% vs. $8.3-70.4 \%$, respectively) and incomplete occlusion of aneurysms increases the risk of rebleeding. It is not clear how incomplete coil occlusion affects the bleeding rate $(3,10,12,18,25,28)$. The main reason for incomplete occlusion was the peri-procedural situation, in that no further coils could be introduced in the aneurysmal sac (25). Aneurysm size is an important factor for coil compaction and reopening over time, but the neck size does not significantly correlate with the occlusion rate $(16,25)$.

\section{Outcomes}

The trend for coiling of aneurysms has grown. According to two prospective, randomized studies of patients with ruptured aneurysms, better outcomes were noted with coiling than clipping $(10,12)$. Some case series have noted no difference in the overall clinical outcome between clipping and coiling (33, 39, 40 ) or better outcome with clipping (35). However, many series have shown better outcomes in patients suitable for coiling than those treated with clipping, with mortality rates of $0.9 \%$ vs. $2.5 \%$, respectively (29). Disability was significantly higher in patients with clipping $(2,10,12)$.

Global cognitive impairment and the risk of epilepsy were observed in coil and clipping, but no significant difference was observed with regard to quality of life, functional outcome, behavioral deficits, and executive functions $(2,12,28,41)$.

\section{Cost and Hospitalization}

Although an economic cost-benefit analysis of different surgical and endovascular treatments is becoming increasingly important in the current health care environment, these studies are relatively few. Some studies have reported that coiling is more expensive than the cost of clipping without providing the additional benefit of decreased morbidity because there were higher procedure costs and a need for more frequent repeat treatments. The total cost of coiling is higher, but this difference is not statistically significant because the cost is substantially compensated by the shorter length of hospital stay in patients with coiling 
than clipping $(2,42,43)$.

Symptomatic vasospasm, post-treatment independency, and mortality rate had a significantly higher incidence in clipping, but incomplete occlusion and hydrocephalus were higher in coiling. There was no difference in procedural complications between both modalities. The rebleeding rate was higher in coiling, but it was not statistically significant. Most reports have shown that coiling is superior to surgery in clinical outcome $(10,12,18,43)$. Surgery compared with endovascular treatment was associated with a longer hospitalization, but lower costs. There is a summary of the currently reported studies in Table 1.

On the basis of published studies, clipping is more favorable in some situations, as follows: 1) the size of an aneurysm is $<5 \mathrm{~mm}$ in patients at low risk; 2) the size is $>5 \mathrm{~mm}$ in those with low-to-moderate risk; and 3) clipping would be more favorable in young patients. Otherwise, coiling would be more favorable, as follows: 1) the size of aneurysm is $<5 \mathrm{~mm}$ in patients with moderate risk; 2) apart from aneurysmal size, patients at high risk or old age; and 3) when the aneurysm is located in the posterior circulation or anterior communicating artery $(2,24,41-44)$.

\section{Unruptured Aneurysms}

With the development of imaging techniques, the incidental detection rate of UIAs has increased. The appropriate management of UIAs remains controversial; however, there has been a tendency for treatment because UIAs have a risk of rupture and the prognosis of SAH is poor. Thus, the aim of treatment is not to avoid rebleeding, but preventive repair $(9,13,16,17$, 19). Various factors have influenced natural history and treatment outcomes: 1) patient factors, such as previous aneurysmal rupture, age, and co-existing medical conditions; 2) aneurysm characteristics, such as size, location, and morphology; and 3) management factors, such as the experience of the surgical or endovascular team and the treating hospital (13). According to previously reported studies, there is a rupture rate of $0-0.05 \%$ /year in patients with aneurysms $<10 \mathrm{~mm}$ in size, $1-3 \% /$ year in patients with aneurysms $10-24$ $\mathrm{mm}$ in size, and $6-8 \%$ in patients with aneurysms $\geq$ $25 \mathrm{~mm}$ in size. Five-year cumulative rupture rates with aneurysms located in the internal carotid artery, anterior communicating or anterior cerebral artery, or middle cerebral artery were $0 \%, 2.6 \%, 14.5 \%$, and $40 \%$ for aneurysms $<7 \mathrm{~mm}, 7-12 \mathrm{~mm}, 13-24 \mathrm{~mm}$, and $\geq$ $25 \mathrm{~mm}$ in size, respectively, compared with rates of $2.5 \%, 14.5 \%, 18.4 \%$, and $50 \%$, respectively, for the same size categories involving the posterior circulation and posterior communicating artery aneurysms. These rates were often equal to or exceeded by the risks associated with surgical or endovascular repair of comparable lesions $(13,16,17)$. Although there is very little direct comparison between coiling and clipping in

Table 1. Summary Data of the Publications that compare the Effects of Aneurysm Occlusion Techniques in Ruptured Aneurysms

\begin{tabular}{|c|c|c|c|c|c|c|c|c|c|c|c|}
\hline $\begin{array}{l}\text { Author }{ }^{\text {Ref }} \text {. } \\
\text { year }\end{array}$ & $\begin{array}{c}\text { Vasospasm } \\
\text { (clip/coil) } \\
\%\end{array}$ & $\begin{array}{c}\text { Infarction } \\
\text { (clip/coil) } \\
\%\end{array}$ & $\begin{array}{c}\text { Disability } \\
\text { (clip/coil) } \\
\%\end{array}$ & $\begin{array}{l}\text { Hydrocephalus } \\
\text { (clip/coil) } \\
\%\end{array}$ & $\begin{array}{l}\text { Is Cost } \\
\text { (expensive) }\end{array}$ & $\begin{array}{l}\text { Hospitalization } \\
\text { (more long) } \\
\text { day }\end{array}$ & $\begin{array}{c}\text { Rebleeding } \\
\text { (clip/coil) } \\
\%\end{array}$ & $\begin{array}{l}\text { Complete } \\
\text { obliteration } \\
\text { (clip/coil) \% }\end{array}$ & $\begin{array}{l}\text { Outcome } \\
\text { (better) }\end{array}$ & $\begin{array}{l}\text { Procedural } \\
\text { Complication } \\
\text { (clip/coil) \% }\end{array}$ & $\begin{array}{c}\text { Mortality } \\
\text { (clip/coil) } \\
\%\end{array}$ \\
\hline $\begin{array}{l}\text { Moleyneux } \\
\text { et } \mathrm{al}^{10}, 2002 \\
\text { Hoh et } \mathrm{al}^{35} \text {, }\end{array}$ & 2 & $\mathrm{n}$ & $28.1 / 17.9$ & $\mathrm{n}$ & $\mathrm{n}$ & $\mathrm{n}$ & $3.9 / 5.3$ & $\mathrm{n}$ & Coil & $\mathrm{n}$ & $8.3 / 7.5$ \\
\hline $\begin{array}{l}2004 \\
\text { Moleyneux }\end{array}$ & NS & $15 / 17$ & $n$ & $\mathrm{n}$ & $n$ & $n$ & $\mathrm{n}$ & $\mathrm{n}$ & Clip & $n$ & NS \\
\hline $\begin{array}{l}\text { et } \mathrm{al}^{12}, 2005 \\
\text { Taha et } \mathrm{al}^{18} \text {, }\end{array}$ & $\mathrm{n}$ & $\mathrm{n}$ & $30.9 / 23.5$ & $\mathrm{n}$ & $n$ & NS & $3.8 / 4.8$ & $n$ & Coil & $n$ & NS \\
\hline $\begin{array}{l}2006 \\
\text { Varelas }\end{array}$ & $45.4 / 17.4$ & $\mathrm{n}$ & $n$ & $25 / 20.8$ & $\mathrm{n}$ & $\mathrm{n}$ & $n$ & $\mathrm{n}$ & Coil & $19.3 / 14.2$ & $9.6 / 14.6$ \\
\hline $\begin{array}{l}\text { et } a^{32}, 2006 \\
\text { Yu et } a{ }^{43}\end{array}$ & $n$ & $\mathrm{n}$ & $14.1 / 8.3$ & $44 / 50$ & $n$ & NS & $10.4 / 6.4$ & $n$ & $\mathrm{n}$ & $n$ & NS \\
\hline $\begin{array}{l}2007 \\
\text { Natarajan }\end{array}$ & $n$ & $9 / 3.7$ & $33.7 / 21.1$ & $4.49 / 0$ & Coil & NS & $n$ & $95 / 89$ & Coil & $40 / 10$ & $\mathrm{~N}$ \\
\hline $\begin{array}{l}\text { et } \mathrm{a}^{3}, 2008 \\
\text { Zubair Tahir }\end{array}$ & ir $66 / 52$ & 21.6/37.7 & $12.4 / 11.5$ & $14 / 19$ & $n$ & $n$ & $n$ & $92.4 / 77.8$ & NS & $4.8 / 5.8$ & $9 / 16$ \\
\hline et $\mathrm{al}^{2}, 2009$ & $\mathrm{n}$ & $32 / 17$ & $n$ & $\mathrm{n}$ & Coil & $12 / 7$ & $\mathrm{n}$ & $100 / 96$ & NS & $\mathrm{n}$ & $6 / 4$ \\
\hline
\end{tabular}

Ref; reference number, NS; not significant difference, n; no described 


\section{Comprehension of Two Modalities}

patients with UIAs only, the mortality, morbidity, and peri-procedural complication rate was $0-0.6 \%, 0.27-$ $7 \%$, and $10.1 \%$ in patients with coiling, respectively, and $0-7 \%, 0.9-10.9 \%$, and $9.0-15.3 \%$ in those with clipping, respectively $(9,13,16,19,45-48)$. Mortality and morbidity are higher in clipping, but the rate of peri-procedural complications is significantly different.

Some literature recommends when treating UIAs, coiling should be considered the first treatment option. When aneurysms are unsuitable for coiling, surgical treatment could be considered as an alternative. Also, conservative treatment should be considered in the following situations: older patient age, decreased life expectancy, co-morbid medical conditions, and asymptomatic, very small aneurysms ( $\leq 2 \mathrm{~mm} ; 13$, 16). The final decision should be carefully considered about the risks and benefits of each treatment, including observation and patent preference.

\section{CONCLUSION}

The goal of this review was not to provide a discussion about which treatment modality is superior in patients with of ruptured aneurysms and UIA. Through a review of previously published results, we want to understand the two treatment modalities (coiling and clipping) properly and help determine which treatment modality will provide the best outcome with the lowest risk for each patient.

The trend and decision to treat with coiling or clipping is constantly changing due to advances in the techniques. Thus, a neurointerventional and neurosurgical team approach is important to the patient with intracranial aneurysms.

Acknowledgment: This paper was supported by Wonkwang Institute of Clinical Medicine in 2010.

\section{References}

1. Anne G. Osborn. Diagnostic neuroradiology: Intracranial aneurysms. St Louis, Mo: Mosby, 1994; 248-249

2. Zubair Tahir M, Enam SA, Pervez Ali R, Bhatti A, ul Haq T. Cost-effectiveness of clipping vs coiling of intracranial aneurysms after subarachnoid hemorrhage in a developing country-a prospective study. Surg Neurol 2009;72:355-360

3. Natarajan SK, Sekhar LN, Ghodke B, Britz GW, Bhagawati D, Temkin N. Outcomes of ruptured intracranial aneurysms treated by microsurgical clipping and endovascular coiling in a highvolume center. AJNR Am J Neuroradiol 2008;29:753-759

4. Hop JW, Rinkel GJ, Algra A, van Gijn J. Case-fatality rates and functional outcome after subarachnoid hemorrhage: a systematic review. Stroke 1997;28:660-664

5. Schievink WI, Wijdicks EF, Parisi JE, Piepgras DG, Whisnant JP.
Sudden death from aneurysmal subarachnoid hemorrhage. Neurology 1995;45:871-874

6. Longstreth WT Jr, Nelson LM, Koepsell TD, van Belle G. Clinical course of spontaneous subarachnoid hemorrhage: a population-based study in King County, Washington. Neurology 1993;43:712-718

7. Rinkel GJ, Djibuti M, Algra A, van Gijn J. Prevalence and risk of rupture of intracranial aneurysms: a systematic review. Stroke 1998;29:251-256

8. de Oliveira JG, Beck J, Ulrich C, Rathert J, Raabe A, Seifert V. Comparison between clipping and coiling on the incidence of cerebral vasospasm after aneurysmal subarachnoid hemorrhage: a systematic review and meta-analysis. Neurosurg Rev 2007;30:2230

9. Im SH, Han MH, Kwon OK, Kwon BJ, Kim SH, Kim JE, et al. Endovascular coil embolization of 435 small asymptomatic unruptured intracranial aneurysms: procedural morbidity and patient outcome. AJNR Am J Neuroradiol 2009;30:79-84

10. Molyneux A, Kerr R, Stratton I, Sandercock P, Clarke M, Shrimpton J, et al. International Subarachnoid Aneurysm Trial (ISAT) of neurosurgical clipping versus endovascular coiling in 2143 patients with ruptured intracranial aneurysms: a randomised trial. Lancet 2002;360:1267-1274

11. Lee HS, Kim YJ, You SH, Jang YG, Rhee WT, Lee SY. The incidence of aneurismal subarachnoid hemorrhage in Youngdong district, Korea. J Korean Neurosurg Soc 2007;42:258-264

12. Molyneux AJ, Kerr RS, Yu LM, Clarke M, Sneade M, Yarnold JA, et al. International subarachnoid aneurysm trial (ISAT) of neurosurgical clipping versus endovascular coiling in 2143 patients with ruptured intracranial aneurysms: a randomised comparison of effects on survival, dependency, seizures, rebleeding, subgroups, and aneurysm occlusion. Lancet 2005;366:809817

13. Bederson JB, Awad IA, Wiebers DO, Piepgras D, Haley EC Jr, Brott $\mathrm{T}$, et al. Recommendations for the management of patients with unruptured intracranial aneurysms: a Statement for healthcare professionals from the Stroke Council of the American Heart Association. Stroke 2000;31:2742-2750

14. Hoh BL, Carter BS, Budzik RF, Putman CM, Ogilvy CS. Results after surgical and endovascular treatment of paraclinoid aneurysms by a combined neurovascular team. Neurosurgery 2001;48:78-89

15. Lawton MT, Quinones-Hinojosa A, Sanai N, Malek JY, Dowd CF. Combined microsurgical and endovascular management of complex intracranial aneurysms. Neurosurgery 2003;52:263-274

16. van Rooij WJ, Sluzewski M. Procedural morbidity and mortality of elective coil treatment of unruptured intracranial aneurysms. AJNR Am J Neuroradiol 2006;27:1678-1680

17. Wiebers DO, Whisnant JP, Huston J 3rd, Meissner I, Brown RD Jr, Piepgras DG, et al. Unruptured intracranial aneurysms: natural history, clinical outcome, and risks of surgical and endovascular treatment. Lancet 2003;362:103-110

18. Taha MM, Nakahara I, Higashi T, Iwamuro Y, Iwaasa M, Watanabe Y, et al. Endovascular embolization vs surgical clipping in treatment of cerebral aneurysms: morbidity and mortality with short-term outcome. Surg Neurol 2006;66:277-284

19. Nussbaum ES, Madison MT, Myers ME, Goddard J. Microsurgical treatment of unruptured intracranial aneurysms. A consecutive surgical experience consisting of 450 aneurysms 


\section{See Sung Choi, et al.}

treated in the endovascular era. Surg Neurol 2007;67:457-464

20. Doerfler A, Wanke I, Goericke SL, Wiedemayer H, Engelhorn T, Gizewski ER, et al. Endovascular treatment of middle cerebral artery aneurysms with electrolytically detachable coils. AJNR Am J Neuroradiol 2006;27:513-520

21. Stoodley MA, Macdonald RL, Weir BK. Surgical treatment of middle cerebral artery aneurysms. Neurosurg Clin N Am 1998;9: 823-834

22. Regli L, Dehdashti AR, Uske A, de Tribolet N. Endovascular coiling compared with surgical clipping for the treatment of unruptured middle cerebral artery aneurysms: an update. Acta Neurochir Suppl 2002;82:41-46

23. Regli L, Uske A, de Tribolet N. Endovascular coil placement compared with surgical clipping for the treatment of unruptured middle cerebral artery aneurysms: a consecutive series. $J$ Neurosurg 1999;90:1025-1030

24. Cai Y, Spelle L, Wang H, Piotin M, Mounayer C, Vanzin JR, et al. Endovascular treatment of intracranial aneurysms in the elderly: single-center experience in 63 consecutive patients. Neurosurgery 2005;57:1096-1102

25. Mordasini P, Schroth G, Guzman R, Barth A, Seiler RW, Remonda L. Endovascular treatment of posterior circulation cerebral aneurysms by using Guglielmi detachable coils: a 10-year single-center experience with special regard to technical development. AJNR Am J Neuroradiol 2005;26:1732-1738

26. Peter DL, Winn HR. Surgical options for cerebral aneurysms. In: Winn HR eds. YOUMANS Neurological surgery: vascular and epilepsy, 5th ed. Pennsylvania, Philadelphia: Sounders, 2003;1799

27. Hohlrieder M, Spiegel M, Hinterhoelzl J, Engelhardt K, Pfausler $\mathrm{B}, \mathrm{Kampfl} \mathrm{A}$, et al. Cerebral vasospasm and ischaemic infarction in clipped and coiled intracranial aneurysm patients. Eur J Neurol 2002;9:389-399

28. Koivisto T, Vanninen R, Hurskainen H, Saari T, Hernesniemi J, Vapalahti M. Outcomes of early endovascular versus surgical treatment of ruptured cerebral aneurysms. A prospective randomized study. Stroke 2000;31:2369-2377

29. Crocker M, Corns R, Hampton T, Deasy N, Tolias CM. Vascular neurosurgery following the International Subarachnoid Aneurysm Trial: modern practice reflected by subspecialization. J Neurosurg 2008;109:992-997

30. Brilstra EH, Rinkel GJ, van der Graaf Y, van Rooij WJ, Algra A. Treatment of intracranial aneurysms by embolization with coils: a systematic review. Stroke 1999;30:470-476

31. David CA, Vishteh AG, Spetzler RF, Lemole M, Lawton MT, Partovi S. Late angiographic follow-up review of surgically treated aneurysms. J Neurosurg 1999;91:396-401

32. Varelas P, Helms A, Sinson G, Spanaki M, Hacein-Bey L. Clipping or coiling of ruptured cerebral aneurysms and shuntdependent hydrocephalus. Neurocrit Care 2006;4:223-228

33. Dehdashti AR, Mermillod B, Rufenacht DA, Reverdin A, de Tribolet N. Does treatment modality of intracranial ruptured aneurysms influence the incidence of cerebral vasospasm and clinical outcome? Cerebrovasc Dis 2004;17:53-60

34. Gruber A, Ungersböck K, Reinprecht A, Czech T, Gross C, Bednar M, et al. Evaluation of cerebral vasospasm after early surgical and endovascular treatment of ruptured intracranial aneurysms. Neurosurgery 1998;42:258-267

35. Hoh BL, Topcuoglu MA, Singhal AB, Pryor JC, Rabinov JD,
Rordorf GA, et al. Effect of clipping, craniotomy, or intravascular coiling on cerebral vasospasm and patient outcome after aneurysmal subarachnoid hemorrhage. Neurosurgery 2004;55:779-786

36. Casasco AE, Aymard A, Gobin YP, Houdart E, Rogopoulos A, George B, et al. Selective endovascular treatment of 71 intracranial aneurysms with platinum coils. J Neurosurg 1993;79:3-10

37. Dehdashti AR, Rilliet B, Rufenacht DA, de Tribolet N. Shuntdependent hydrocephalus after rupture of intracranial aneurysms: a prospective study of the influence of treatment modality. $J$ Neurosurg 2004;101:402-407

38. Henkes H, Fischer S, Weber W, Miloslavski E, Felber S, Brew S, et al. Endovascular coil occlusion of 1811 intracranial aneurysms: early angiographic and clinical results. Neurosurgery 2004;54: 268-280

39. Rabinstein AA, Pichelmann MA, Friedman JA, Piepgras DG, Nichols DA, McIver JI, et al. Symptomatic vasospasm and outcomes following aneurysmal subarachnoid hemorrhage: a comparison between surgical repair and endovascular coil occlusion. J Neurosurg 2003;98:319-325

40. Frazer D, Ahuja A, Watkins L, Cipolotti L. Coiling versus clipping for the treatment of aneurysmal subarachnoid hemorrhage: a longitudinal investigation into cognitive outcome. Neurosurgery 2007;60:434-441

41. Proust F, Martinaud O, Gérardin E, Derrey S, Levéque S, Bioux $\mathrm{S}$, et al. Quality of life and brain damage after microsurgical clip occlusion or endovascular coil embolization for ruptured anterior communicating artery aneurysms: neuropsychological assessment. J Neurosurg 2009;110:19-29

42. Hoh BL, Chi YY, Dermott MA, Lipori PJ, Lewis SB. The effect of coiling versus clipping of ruptured and unruptured cerebral aneurysms on length of stay, hospital cost, hospital reimbursement, and surgeon reimbursement at the university of Florida. Neurosurgery 2009;64:614-619

43. Yu SC, Wong GK, Wong JK, Poon WS. Endovascular coiling versus neurosurgical clipping for ruptured intracranial aneurysms: significant benefits in clinical outcome and reduced consumption of hospital resources in Hong Kong Chinese patients. Hong Kong Med J 2007;13:271-278

44. Ausman JI. The International Subarachnoid Aneurysm Trial II: comparison of clipping vs coiling: key questions. Are the results of the study generalizable? Should clipping be done for patients less than 40 years of age? Surg Neurol 2008;70:104-107

45. Lanterna LA, Tredici G, Dimitrov BD, Biroli F. Treatment of unruptured cerebral aneurysms by embolization with Guglielmi detachable coils: case-fatality, morbidity, and effectiveness in preventing bleeding-a systematic review of the literature. Neurosurgery 2004;55:767-775

46. King JT, Berlin JA, Flamm ES. Morbidity and mortality from elective surgery for asymptomatic, unruptured, intracranial aneurysms: a meta-analysis. J Neurosurg 1994;81:837-842

47. Raaymakers TW, Rinkel GJ, Limburg M, Algra A. Mortality and morbidity of surgery for unruptured intracranial aneurysms: a meta-analysis. Stroke 1998;29:1531-1538

48. Pandey AS, Koebbe C, Rosenwasser RH, Veznedaroglu E. Endovascular coil embolization of ruptured and unruptured posterior circulation aneurysms: review of a 10-year experience. Neurosurgery 2007;60:626-636 


\section{두개내 동맥류의 두 가지 치료법에 대한 이해: 혈관내 색전술과 클립 결찰술}

${ }^{1}$ 원광대학교 의과대학 원광대학교병원 영상의학과

\section{최시성' · 전세정'}

뇌동맥류의 파열은 지주막하 출혈을 일으키며, 이에 의한 사망률과 이환율은 전 세계적인 보건문제가 되고 있 다. 1970년대부터 클립 결찰술이 파열성 뇌동맥류의 보편적인 치료방법이었다. 그러나 1990년에 Guglielmi detachable coil (GDC)가 발명되어 임상에 소개되었고 이로 인해 신경중재적 치료 기술의 발전을 가져왔으며, 개 두술 없이 재출혈의 위험을 감소시킬 수 있었다. 따라서 현재 뇌동맥류의 혈관내 색전술의 빈도가 전 세계적으로 증가하고 있으며 보편화되고 있다. 치료방법이 클립 결찰술 또는 혈관내 색전술 이든지 뇌동맥류를 치료하는 목적 은 재출혈을 방지하고, 비파열성 동맥류의 파열을 예방하는 것이다. 두 가지 치료법 모두 각각의 장점과 단점이 있 고, 뇌 동맥류 치료에 어떤 방법이 더 효과적인가에 대한 물음은 아직도 논쟁 중이다. 이에 저자들은 이전에 발표 된 논문들을 바탕으로, 뇌동맥류의 두 가지 치료방법의 실효성에 대해 알아보고 이에 대한 이해를 높이고자 한다.

Key Words : Aneurysm; Clipping; Coiling; Subarachnoid hemorrhage 